\title{
技術報告
}

[環境化学（Journal of Environmental Chemistry）Vol.16, No.1, pp.133-146, 2006]

\section{オンライン $\mathrm{GPC} / \mathrm{GC}$ による絶縁油中低濃度 PCB の簡易自動分析法に関する検討}

\author{
小林 信弥, 和田 豊仁, 日根 隆, 山田 恭子* \\ (株)島津製作所分析計測事業部応用技術部（テ604-8511 京都府京都市中京区西ノ京桑原町1） \\ *(株)島津総合分析試験センター（２529-1304 神奈川県秦野市堀山下380-1） \\ [平成17年11月10日受理］

\section{Study of using an Online GPC/GC for Simplified Automated Analysis of Low Concentrations of PCBs in Insulating Oil} \\ Nobuya KOBAYASHI, Toyohito WADA, Takashi HINE and Kyoko YAMADA* \\ Shimadzu Corporation, Analytical Application Department \\ (1 Nishinokyo-Kuwabara, Nakagyo, Kyoto, Kyoto 604-8511) \\ * Shimadzu Analytical \& Measuring Center, Inc. \\ (380-1 Horiyamashita, Hadano, Kanagawa 259-1304)
}

[Received November 10, 2005]

\begin{abstract}
Summary
A simple and precise analytical method is needed for checking insulating oil contaminated with low concentrations of PCBs. Conventional methods for the analysis of PCB-contaminated insulating oil samples require long pretreatment time with highly skilled technicians. The aim of the present study was to develop a simplified automated analytical method that would reduce the amount of labor required for analyzing low concentrations of PCBs in insulating oil. An online GPC/GC was built using an existing HPLC and a GC. After optimization of analytical conditions of the automated GPC/GC system by using standard PCB solution, standard-added waste insulating oils were pretreated with sulfuric acid and analyzed. Repeatabilities (RSD) of the analysis of PCB-containing waste oil at $0.5 \mathrm{mg} / \mathrm{kg}$ were from 3.3 $\%$ to $6.8 \%$, and the method detection limit $(3 \sigma)$ and the method quantification limit $(10 \sigma)$ were $0.1 \mathrm{mg} / \mathrm{kg}$ and $0.34 \mathrm{mg} / \mathrm{kg}$, respectively. Good stability and reliability of the analysis was shown in the repeated analysis of 137 samples for one week, confirming applicability of the system for insulating waste oils contaminated with low concentrations of PCBs.
\end{abstract}

Key words: PCBs, Insulating oil, GPC/GC, Pretreatment, Automated analysis

\section{1. はじめに}

1950年代からコンデンサ, 変圧器等の電気設備に使用 されてきたPCB は日本国内においてはその高い毒性ゆ えに1972年以降製造・使用が禁止されている。その後,
特別管理産業廃棄物に指定され，厳重な管理が義務付け られているが長期保管による紛失が発生しており，保管 の継続による環境污染が懸念されている。2001年には $\lceil\mathrm{PCB}$ 廃棄物の適正な処理の推進に関する特別措置法」 が施行され, PCB 廃棄物を所有する事業者等には保管状 
況の届け出，一䇥期間内に適正に処分することが義務づ けられたここ机に伴い、国、都道府県ではPCB 廃萧物処 理基本計画の策定や全国各地での拠点的広域処理施設の 整備など PCB 廃容物処理事業が進めら机つつあり, 国 内 5 ヶ所で処理プラントを稼動させ，2016年 3 月までに 処理が行わ机る予定である。また，近年，これとは別 に, 変圧器 (トランス) など重電機器内の絶縁油中から 微量 (数 $\mathrm{ppm}$ 程度) の $\mathrm{PCB}$ が㭘出された事例, また, $\mathrm{OF}$ ケーブル(絶縁油を用いる地中送電線)の絶縁油か ら微量の $\mathrm{PCB}$ が検出さ机た事例が報告さ机ており, 経 済産業省および環境省はPCB 廃寁物として適性に対応 する必要があるとして2003年に「低濃度 PCB 污染物対 策検討委員会」を設置し, 低濃度 PCB 活染電機機器の特 定、対策を娭討している: 現在，これらのPCBに污染さ 机ている可能性のある検查対象検体数は数百万にのぼる といわ机ているが，絶緣油中の PCB 分析においてはそ の前処理操作，分析操作に多くの時間と熟練した技術を 要するため，より簡健な分析方法の開発が急務である。

絶縁油中 PCB 分析法としては, HPLCを用いた順相カ ラム-GC/MS 法"，NCIによる GC/MS 法”および松原らの $\mathrm{GPC}$ カラム-GC/ECD 法 ${ }^{3)}$ 等がある。松原らは食品中の 農薬分析の前処理に用いら机ている GPC 法を絶縁油と PCB の分離に適用し，硫酸処理と組み合わせることに よって $95 \%$ 以上の絶縁油を除去できるとしている。報告 者らは既にオンライン GPC/GC システムを構築し、「ポ リマーの分子量抄よび添加敦の一斉分析」に適用した経 験があり"，松原らの方法をこのシステムに組み込めば 分析条件を変えるだけで絶縁油中の微量 PCB 分析が自 動化可能であると判断し、検討を行った。

\section{2. 実験方法}

\section{1 試薬および溶媒}

実験に用いた試薬および溶媒は次のものである。 $\mathrm{PCB}$ 標準品：GLサイエンス社製カネクロールキット (KC-300, 400, 500, 600)

GPC 用移動相：シクロヘキサン JIS K8464S 規格 和光純薬工業株式会社製 酢酸エチル JIS K8361S 規格

和光純薬工業株式会社製 試料注入用溶媒：テトラヒドロフラン (THF) ( )規格

和光純薬工業株式会社製

\section{2 装置}

GPC/GC システム構築に用いた装置はいずれも島津製 作所製である。システムはLC-10A シリーズを用いた GPC 部とインターフェース部, GC-17AAFwにPTVイン ジェクタを搭載した GC 部抄よびクロマトパック C-R7
Aplusのデー夕処理部から成る。各部の詳細は次のとお りである。

[GPC 部]

送液ポンプ：LC-10AD, 自動試料注入装置: SIL-10A, カラム恒温槽: CTO-10AC, 紫外分光光度計: SPD-10A, 示差屈折計：RID-10A，システムコントローラ：SCL$10 \mathrm{~A}$

[インターフェース部 $]$

高圧流路切換バルブ：FCV-12AH，オプションボック ス L

[GC 部 $]$ GC-17AAFw+ECD-17+PTV $(\mathrm{OCI}-17)$

[データ処理装置部］クロマトパック C-R7Aplus

\section{3 分析の手順とシステムの動作}

GPC/GC システムの構成を Fig. 1 に，また，分析の手 順を下記に示す。

(1) 硫酸処理を行った絶縁油試料を GPC 用移動相（酢 酸エチルノシクロヘキサン混合液）に溶解させた 後, 自動試料注入装置でGPCに注入し, 絶縁油部分 と PCB 部分に分離する。

(2) GPC 用検出器を出た PCB を含志溶出液をトラップ 用ループに導入する。PCB を含む溶出液の量は本実 験に使用したGPCカラムおよび移動相などの分析 条件下では約 $4 \mathrm{~m} \ell$ となり，その全量を GC の PTV に注入するには時間がかかりすぎるため，スプリッ トしてPCB 溶出全領域に渡ってその一部をトラッ プ用ループに入れるようにした。スプリット比の設 定は内径0.3mmのSUSパイプ（Fig.1のR1，R2）の 長さを調整して行った。

(3) 流路を切換えてループ内の PCB を含む GPC 溶出液 を GCのPTVに注入する。

流路の切り替えは高压流路切り替えバルブ（Fig. 1 のV1，V2）を用いて行った。切り替えの時間は，予 め $\mathrm{PCB}$ 標準品を $\mathrm{GPC}$ 分析し，その溶出時間と GPC 移動相流量と溶出液のスプリット比, 配管の死容積 から計算さ机るトラップ用ループヘの移行時間から 算出した。

(4)PTV内にて注入されたGPC 溶出液の大部分を気化, 除去する。

PTV 内のガラスインサートには PCB を捕捉するた めの充填剤が允填さ机ており，一定温度下で溶出液 中の PCB を充填剤に捕捉しながら GPC 溶出液を気 化させ，GCのスプリットラインから排出させる。

( 5 ) PTVの温度を急激に上げ，充填剤に捕捉された $\mathrm{PCB}$ を気化させてキャピラリ GC-ECD で昇温分析 する。

試料注入，流路の切り替え， GC の昇温分析の開始な どは LCのシステムコントローラから制御し自動化した。 


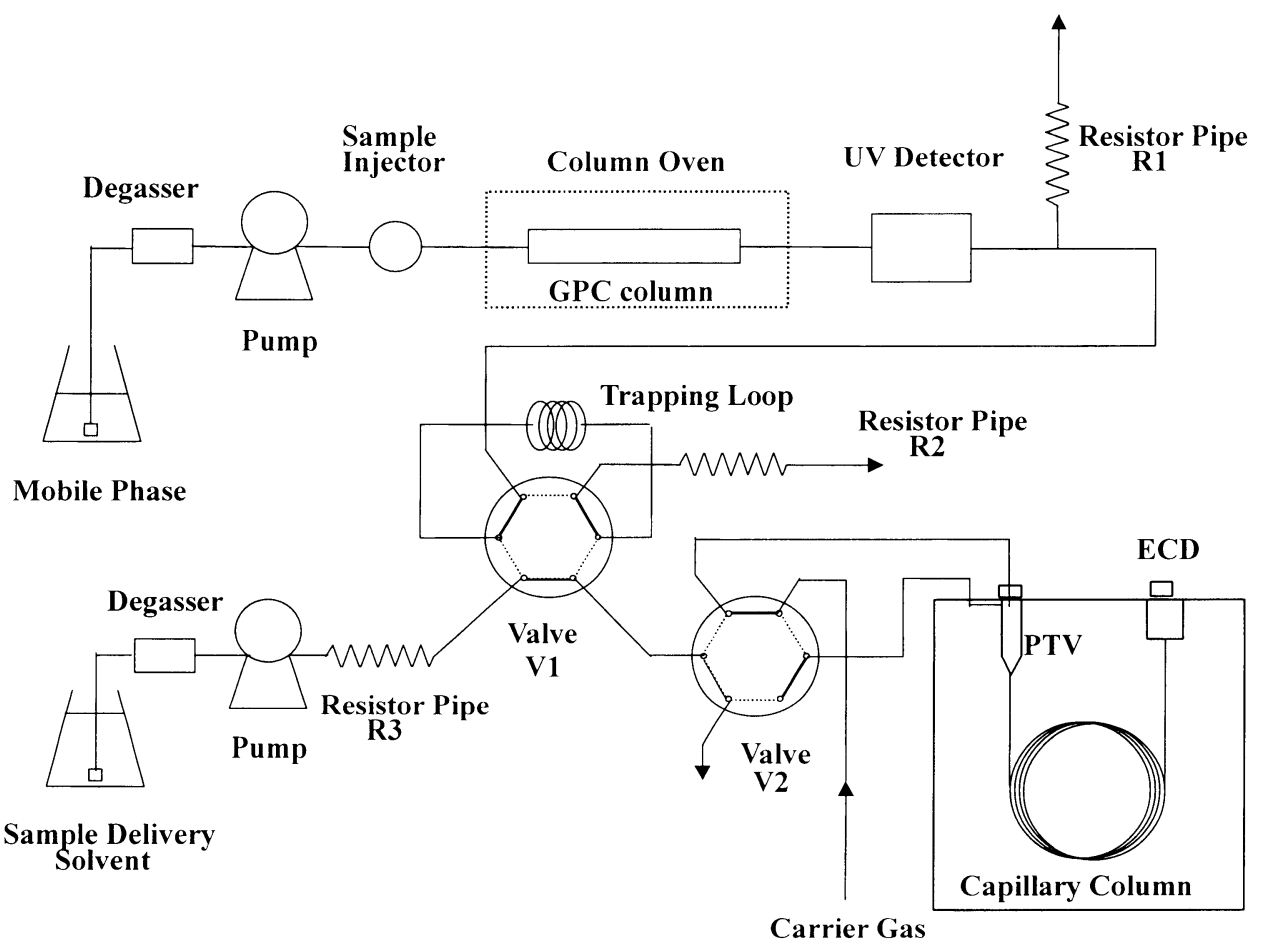

Gas Chromatograph

Fig. 1 The scheme of GPC/GC system

\section{3. 結果と考察}

\section{1 GPC における絶縁油とPCB の溶出挙動}

松原らの前処理方法における絶縁油と $\mathrm{PCB}(\mathrm{KC}-$ $300,400,500,600$ 等量混合品）の GPC カラムからの 溶出挙動について調べた。

カラムは昭和電工社製 CLNpak EV-800 (300mm×8 mmI.D.) + CLNpak EV-SG (100mm $\times 8$ mmI.D.), 移動 相は酢酸エチル/シクロヘキサン $(3 / 7(\mathrm{v} / \mathrm{v}))$ 混合液, 流 速 $1.0 \mathrm{~m} \ell / \mathrm{min}$, カラム温度 $25^{\circ} \mathrm{C} に て$ 行った。カラムから の溶出液は紫外分光光度計 $(254 \mathrm{~nm})$ 抢よび示差屈折計 をカラム出口に直列に接続してモニターした。硫酸処理 を行った絶縁油 (廃油) のクロマトグラムを Fig. 2 に示 す。右のクロマトグラムは示差屈折計によるもの, 左は UV $254 \mathrm{~nm}$ によるものである。示差屈折計のデー夕を見 ると, 絶縁油のほとんどがこの GPCカラム, 移動相系の 浸透限界（11.5〜 12.0minのベースラインの落ち込み部 分）より前に溶出していることがわかる。一方，PCB は 同じ条件下ではFig. 3 (左) に示すように浸透限界以降 の12.5 16.5minの間に広がって溶出している。しか し，浸透限界付近での両者の微妙な重なり具合は試料溶 媒と移動相の組成の違いにより生じるベースラインの落 ち込み（負ピーク）のためはっきりとは確認できない。
この負ピークは試料溶媒と移動相の組成が同じでも，両 者における溶存ガス量に違いがあるだけでも生じるた め, 示差屈折計による测定に扔いては完全に解消するこ とは困難である。そこで, 絶縁油 (廃油) を試料として 用い, GPCによる絶縁油除去効果を GC-FID にて調べ た。GC-FIDの分析条件を Table 1 に示す。Fig. 4 に未処 理の絶縁油, 硫酸処理を行ったもの, 硫酸処理後 GPCを 行ったものを併せたクロマトグラムを示す。硫酸処理の みでは約 $10 \%$ の絶緣油しか除去されていないが，硫酸処 理と GPC 法を併せたものでは92.5〜96\%の絶縁油を除 去することが出来た。この結果は松原らの報告とよく一 致している。

しかし, UV 254nmによるクロマトグラムをみると示 差屈折計において絶縁油の溶出が確認され始めてから暫 くして絶縁油に含まれる強いUV 吸収を持つ成分が溶出 し始め, 絶縁油の大部分が浸透限界付近で溶出し終わっ てもな搈出し続け，25分になってようやく終了する。 PCB はこの微量ではあるが強いUV 吸収を持つ成分にク ロマトグラム上では埋も机た形になっている。つまり, 本カラム, 移動相系ではPCB は絶縁油中に微量に含ま れるUV吸収を持つ成分と完全に分離することは困難で ある。このUV 吸収成分に関しては、佐々木らがアセト ンを移動相とした GPC 法により $\mathrm{PCB}$ と油状物質の分離 


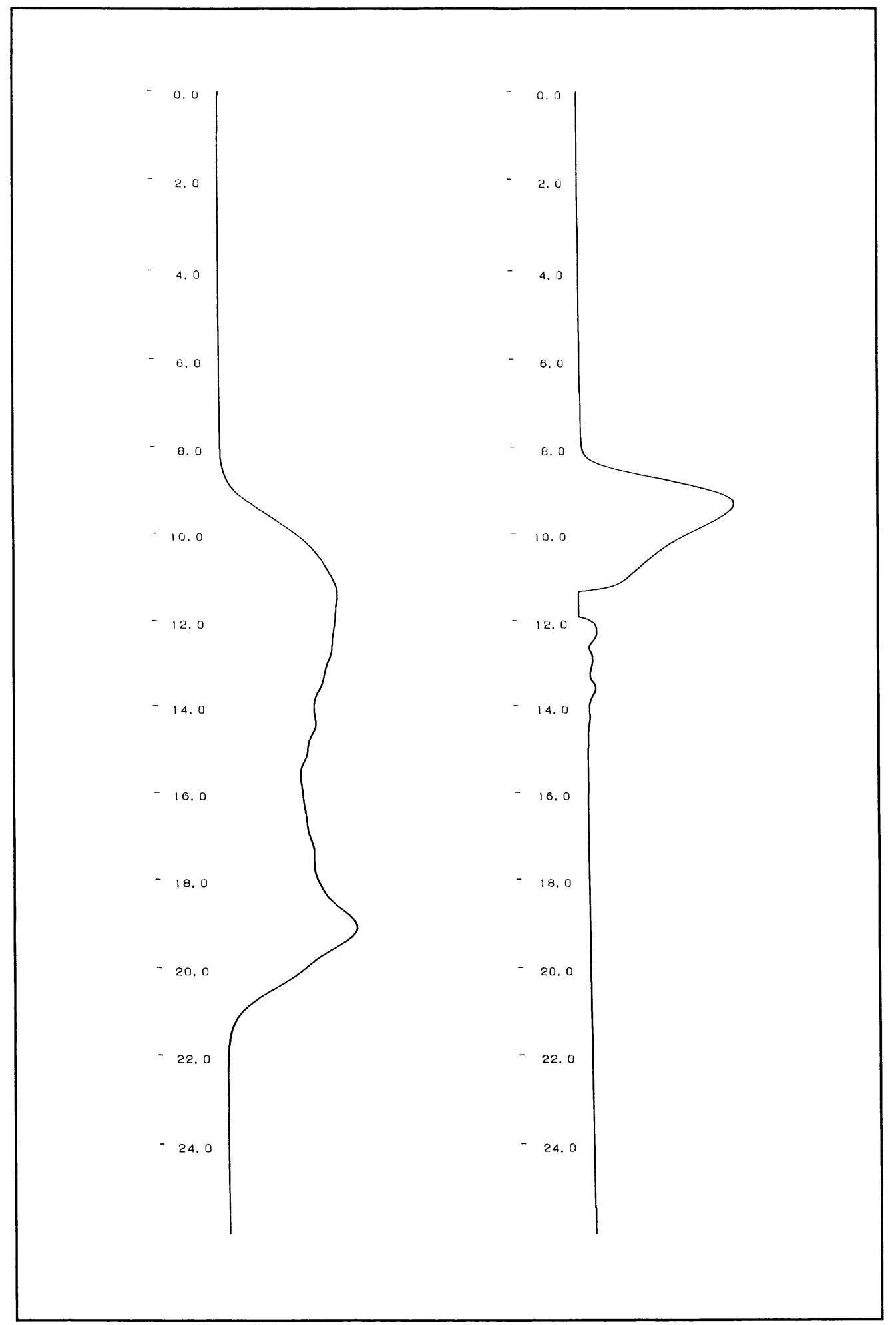

Fig. 2 GPC chromatograms of waste oil (right: RID left: UV (254 nm)) 


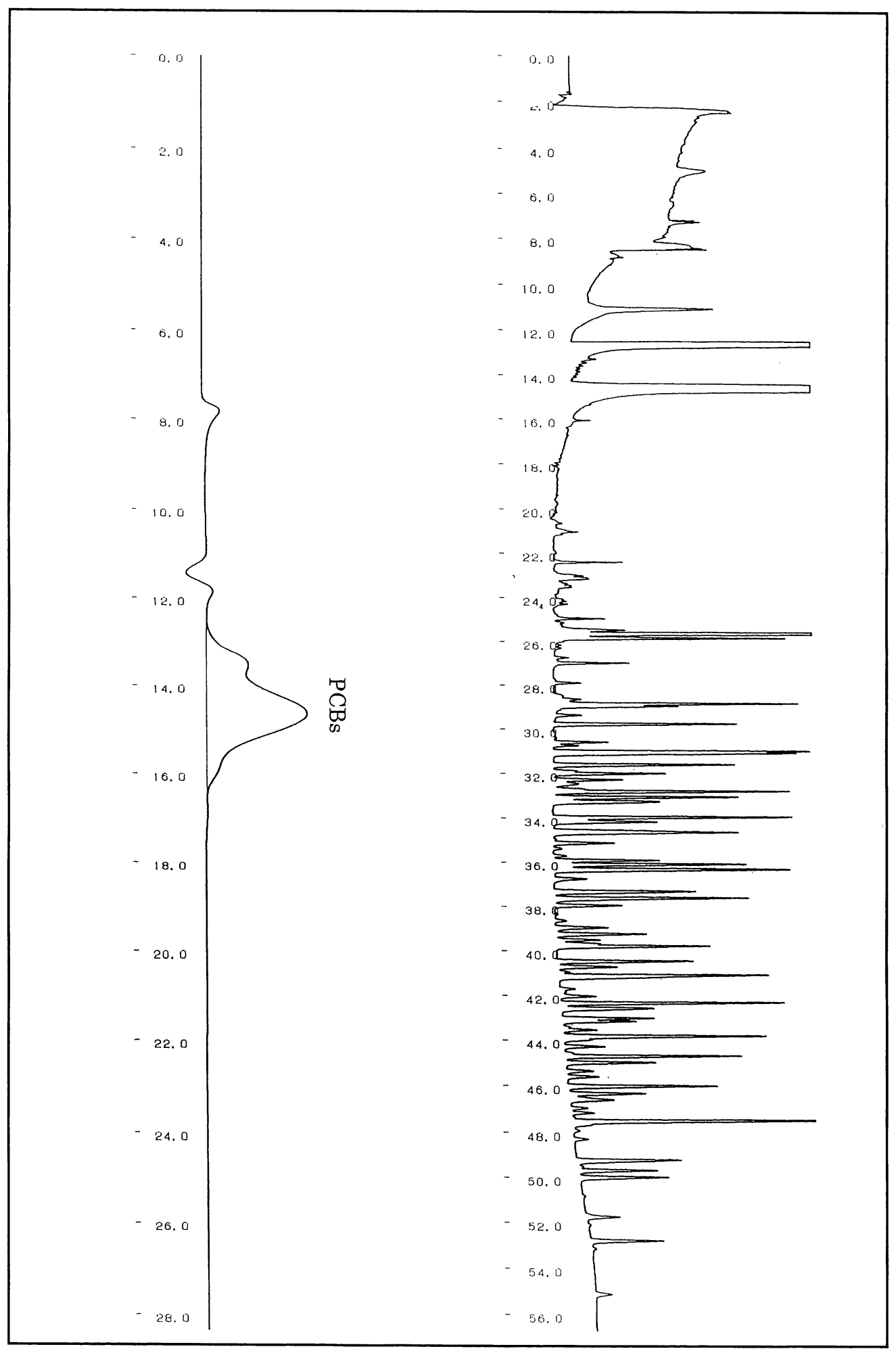

Fig. 3 Chromatograms of PCBs standard (2.0 ppm) (right: GC-ECD left: GPC-UV (254 nm)) 
挙動について調ベ，アントラセン，ピレン，アルキルナ フタレンが溶出している事を報告しておりら, 本 GPC 系 においても同様の多環芳香族等が溶出しているものと推 察する。この溶出挙動はクロマトパターンに多少の違い こそあ机絶縁油試料に共通したものであり，また，硫酸 処理を行ったものも，処理を行わないものに比べUV 吸 収成分が面積值で約20～25\%減少しただけで，挙動に大 きな違いは無かった

\section{2 分析条件の設定および PCB 標準品のクロマトグ ラム}

絶縁油分離用 GPC カラムとしては前述の昭和電工社 製 CLNpak EV を用いたが PCB を含む溶出液の総量を抑

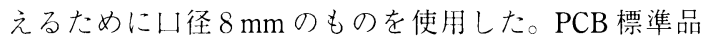
$(\mathrm{KC}-300,400,500,600 の$ 等量混合品2.0ppm GPC 用移

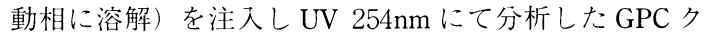
ロマトグラムを Fig. 3 (左)に示す。PCB は浸透限界 (11.5〜12.0min) 以降の12.5〜16.5minに溶出してお り, $\mathrm{PCB}$ を含む溶出液の量は約 $4 \mathrm{~m} \ell$ となる。この全量 をGCのPTVに注入するのは時閒がかかりすぎるため， 1：6にスプリットし, $\mathrm{PCB}$ を含む溶出液の $1 / 7$ を内容 積 $600 \mu \ell$ のラップ用ループに導入した。トラップ用 ループはHPLC 用のSUS 配管 (内径0. $8 \mathrm{~mm}$ ) を用いて作 成した。PTVへの試料注入用溶媒としては注入ラインに 絶縁油, PCB が吸着, 残存しないように溶解性を考虑し て THFを使用した。PTVへの試料注入速度は 100 $\mu \ell / \min$ とした。PCBを捕捉するためのPTV用充填郕と しては Celite 社製の Chromosorb W（80/100メッシュ） $25 \mathrm{mg}$ を用いた。右のクロマトグラムはPTVへの GPC 溶 出液注入完了後, PTVの温度を急激に上げ, 気化した

Table 1 Analytical conditions

Instrument: GC-2010AF + AOC-20i

Column. : UA DX-30 $5 \mathrm{~m} \times 0.25 \mathrm{mmI}$.D. $\mathrm{df}=0.1 \mu \mathrm{m}$

Column Temp.: $60^{\circ} \mathrm{C}(1 \mathrm{~min}) \sim 40^{\circ} \mathrm{C} / \mathrm{min} \sim 200^{\circ} \mathrm{C} \sim 15^{\circ} \mathrm{C} / \min \sim 350^{\circ} \mathrm{C}$

Injection Temp.: $350^{\circ} \mathrm{C}$

Detector:FID

Detector Temp : $360^{\circ} \mathrm{C}$

Carrier Gas: He $7.23 \mathrm{~m} \ell / \mathrm{min}$

(100kPa $177.6 \mathrm{~cm} / \mathrm{s}$ Constant Linear Velocity Mode)

Split Ratio: $1: 2$

Inj.Volume: $1 \mu \ell$

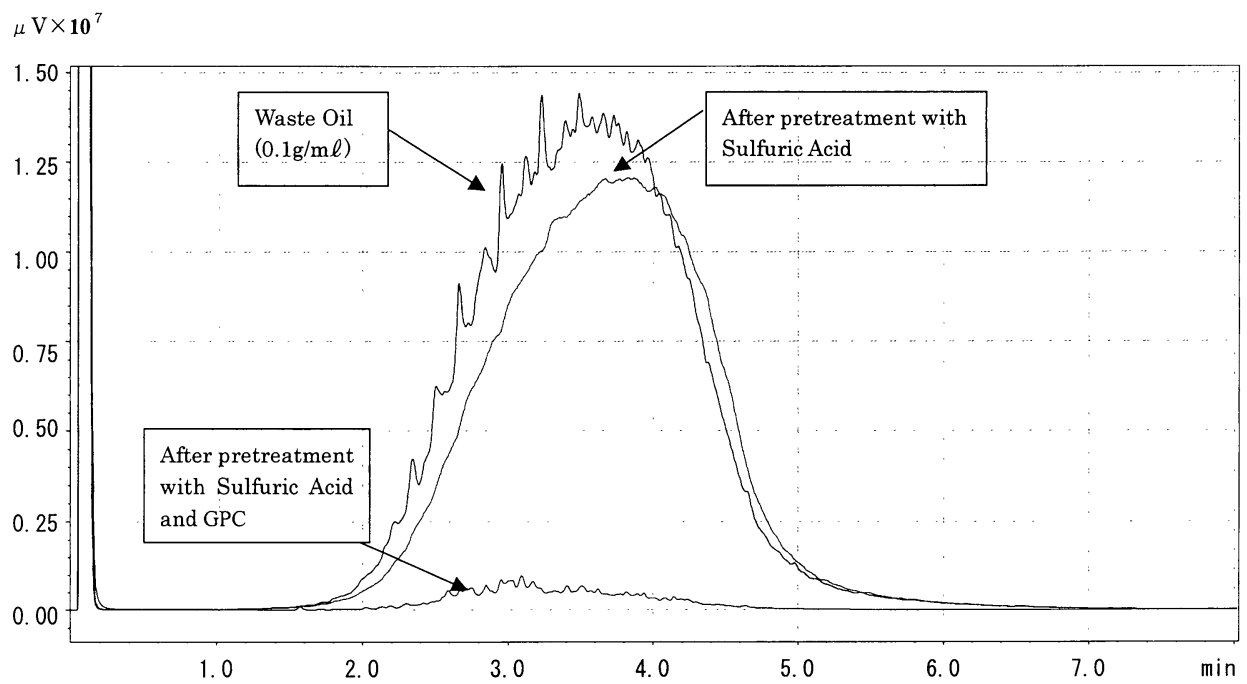

Fig. 4 GC-FID chromatograms of insulating oil (waste oil) 
PCB を GC-ECD にて昇温分析したものである。26min よ り前に現れている数本の大きなピークはPTVへの試料 注入用溶媒として用いた THF 中の不純物由来ピークで あり，26min 以降のピークが PCBのピークである。分析 条件の詳細は Table 2 にまとめた。

\section{3 PCB 標準品添加絶縁油のクロマトグラム}

Fig. 5 に本分析システムにおける移動相ブランク, Fig. 6 に検討用に用いた絶縁油（廃油）のGCクロマトグ ラムを示す。絶縁油（廃油）試料はすべて松原らの前処 理方法に従って Fig. 7 に示す硫酸処理を行った。絶縁油 (廃油)には微量の PCB（約0.15ppm）混入が認められ た（別途オフラインで GC-ECDを使用し再確認）。 Fig. 8 , Fig. 9 に絶縁油 (廃油)にPCB 標準品を0.5ppm および2. $0 \mathrm{ppm} の$ 濃度に添加し, 同様の処理を行った試 料を分析したクロマトグラムを示す。

\section{4 分析再現性と検出限界および定量限界}

特別管理産業廃棄物の判定基準は廃油の場合, $0.5 \mathrm{ppm}$ であるため, 絶縁油 (廃油) に $\mathrm{PCB}$ 標準品を $0.5 \mathrm{ppm} の$ 濃度に添加し, 硫酸処理を行った試料を用い

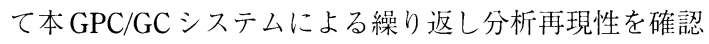
した。PCBの溶出区間全域から他のピークと比較的分離 状態がよく，また，ピーク高さも高いピーク 5 本 (Fig. 9 中の(1)〜（5)に相当するピーク）を選び，それらの ピーク高さ及びピーク面積の再現性, また, これらを含 む全ピークの総ピーク高さ, 総ピーク面積の再現性（n =5）を求めた。それぞれの RSD は3.3〜 6.8\%の範囲に あり，良好な再現性を示した。なお、RSDの算出にあ たっては絶縁油 (廃油) に元々含まれていたPCBは減算 補正した。この結果から PCB の検出下限值 $(3 \sigma)$ は $0.10 \mathrm{ppm}$, 定量下限值 $(10 \sigma)$ は $0.34 \mathrm{ppm}$ であった。な お，一連の分析において GC 側のスプリット比を $1: 100$

Table 2 Analytical conditions

(GPC)

Instrument:LC-10A System

Column : CLNpak EV-SG $(100 \mathrm{~mm} \times 8.0 \mathrm{mmI}$.D. $)$

CLNpak EV-800 (300mm $\times 8.0 \mathrm{mmI} . D$.)

Mobile Phase: Ethyl Acetate / Cyclohexane=3 /7 (v/v)

Flow Rate: $1.0 \mathrm{~m} \ell / \mathrm{min}$

Column Temp.: $25^{\circ} \mathrm{C}$

Detector:SPD-10A $254 \mathrm{~nm}$

Injection Volume: $400 \mu \mathrm{l}$

Effluent Split Ratio: 1:6

Trapping Loop Volume: $600 \mu$ e

(GC)

Instrument: GC-17AAF(ECD-17+OCI-17(PTV))

Column : CBP5-S25-050(25m $\times 0.33 \mathrm{mmI} . \mathrm{D} . \mathrm{df}=0.5 \mu \mathrm{m})$

Column Temp.: $55^{\circ} \mathrm{C}(5 \mathrm{~min}) \sim 15^{\circ} \mathrm{C} / \mathrm{min} \sim 180^{\circ} \mathrm{C}$

$\sim 3^{\circ} \mathrm{C} / \mathrm{min} \sim 280^{\circ} \mathrm{C}(10 \mathrm{~min})$

Carrier Gas: $\mathrm{He} 52 \mathrm{kPa}\left(55^{\circ} \mathrm{C}\right)$

Split Ratio: 1: 100

PTV Packing Material:Chromosorb W(AW,DMCS)

PTV Temp.: $75^{\circ} \mathrm{C}(1 \mathrm{~min}) \sim 30^{\circ} \mathrm{C} / \mathrm{min} \sim 105^{\circ} \mathrm{C}(1 \mathrm{~min})$

$$
\sim 250^{\circ} \mathrm{C} / \mathrm{min} \sim 340^{\circ} \mathrm{C}(52 \mathrm{~min})
$$

Sample Injection Liquid:THF Injection Speed: $100 \mu \mathrm{l} / \mathrm{min}$

Detector:ECD-17 (1nA Range1)

Detector Temp: $340^{\circ} \mathrm{C}$

Makeup Gas: $\mathrm{N}_{2} 75 \mathrm{kPa}$

Data Processor:C-R7A plus 


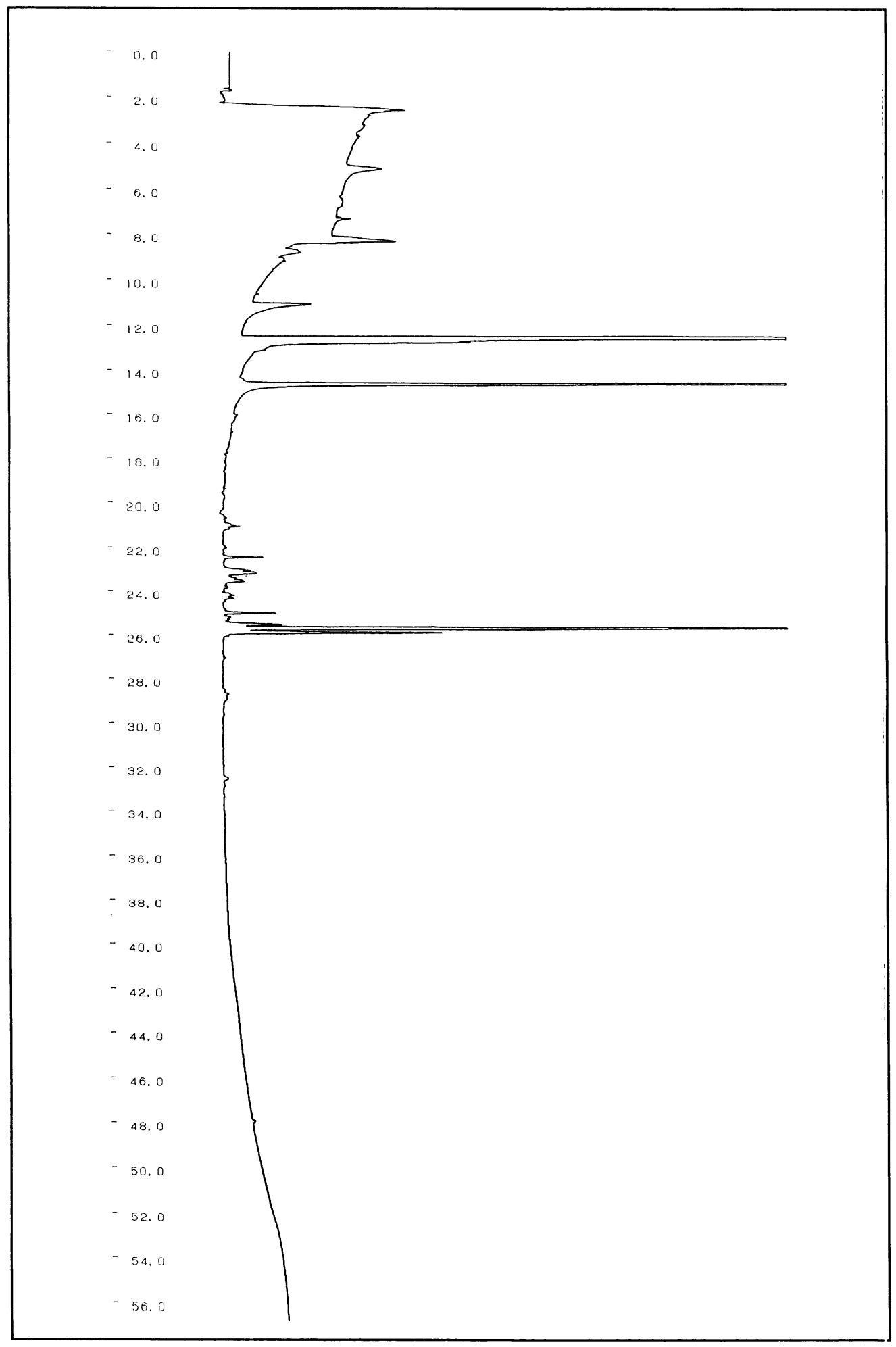

Fig. 5 Chromatogram of blank (GPC mobile phase) 


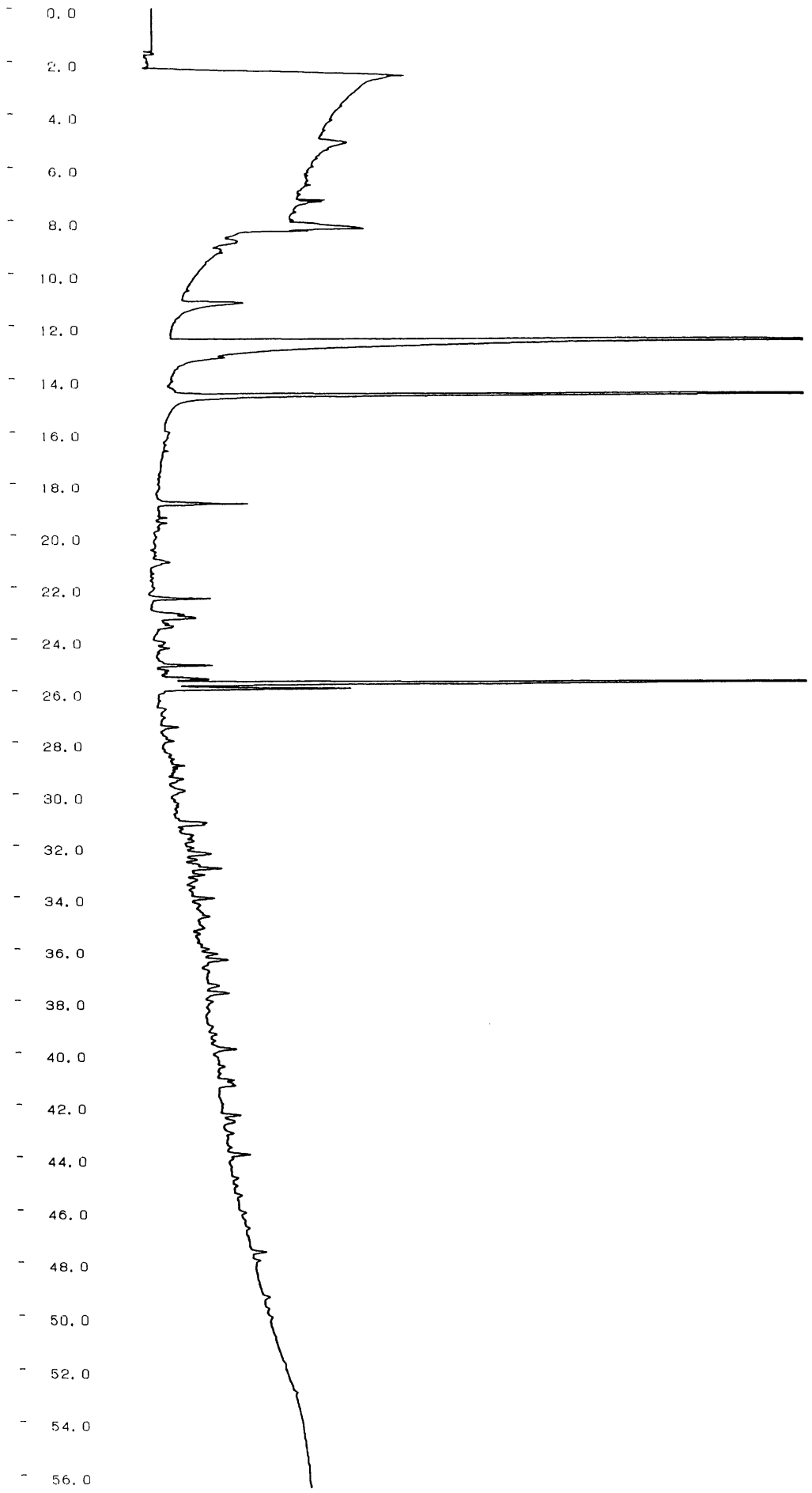

Fig. 6 Chromatogram of waste oil 
に設定したが，このスプリット比を小さく設定すれば検 出下限值，定量下限值はさらに改善されると考える。

\section{5 検量線}

Fig.10に PCB 標準品を用いて作成した検量線を示す。 横軸は PCB 濃度 $(0.2 \sim 5.0 \mathrm{ppm})$, 縦軸は総ピーク高さ および総ピーク面積值である。いずれの検量線もなだら かな曲線となった。

\section{6 分析安定性}

自動化の可能性を探るために絶縁油（廃油）にPCB 標 準品を添加後、硫酸処理した試料を連続分析し，本 $\mathrm{GPC} / \mathrm{GC}$ システムの分析安定性を調べた。PCB 標準品の 添加濃度は2.0ppm とした。これは0.5ppm と2.0ppm 添 加試料で再現性にあまり大きな差がなく（総ピーク高さ の RSD は $0.5 \mathrm{ppm} て ゙ 6.8 \% ， 2.0 \mathrm{ppm}$ で6.2\%)，また， 2.0ppm 添加のほうが PCB の小さなピークの分離状態を 視覚的に確認しやすいためである。分析は137回（約 1 週間）連続して行った。Fig.11にPCB の総ピーク高さの 変動を示す。横軸は10回毎ののべ分析回数，縦軸は平均 值を $100 \%$ とした場合の相対值を表す。ECD を用いた分 析時にしばしば経験することであるが，分析開始後，暫 くは検出感度が増加し，その後は安定する傾向を示し た。ピークの分離状態，ピーク形状などには経時的変化
は認めら机ず良好であった。

\section{7 保持時間の変化}

絶縁油中の PCB を分析する場合, 絶縁油の除去が十 分でないと PCB の保持時間が大幅に変動することは経 験的によく知ら机ている。こ扎はカラム内に残留した絶 縁油が擬似的な液相として作用するためと考元られる。 137回（約 1 週間）の連続分析において, PCBのピーク の保持時間はいずれも最終的に分析開始時のものに比べ て約 1 \%長くなった。前述の如く, GPC 法でも完全に絶 縁油を除去することは困難であり、特に今回のように分 析カラムとしてキャピラリカラムを用いた場合は相対的 な液相量が少なくなるため，この影響が現れたものと考 えら狄る。長期連続分析に扔いて正確な定量を継続して 行うためには PCB 各ピークの保持時間の確認は不可欠 であり，今後の課題であるが，GPCカラムを 2 本直列接 続してさらに絶縁油の除去効果を上げる ${ }^{6.7)}$ ，内部標準物 質を添加して保持時間の補正を行う，あるいは定期的に カラムのエージングを行う等の対策が必要と考えられ る。

\section{4. まとめ}

オンライン $\mathrm{GPC} / \mathrm{GC}$ を用いて絶縁油中低濃度 $\mathrm{PCB}$ の

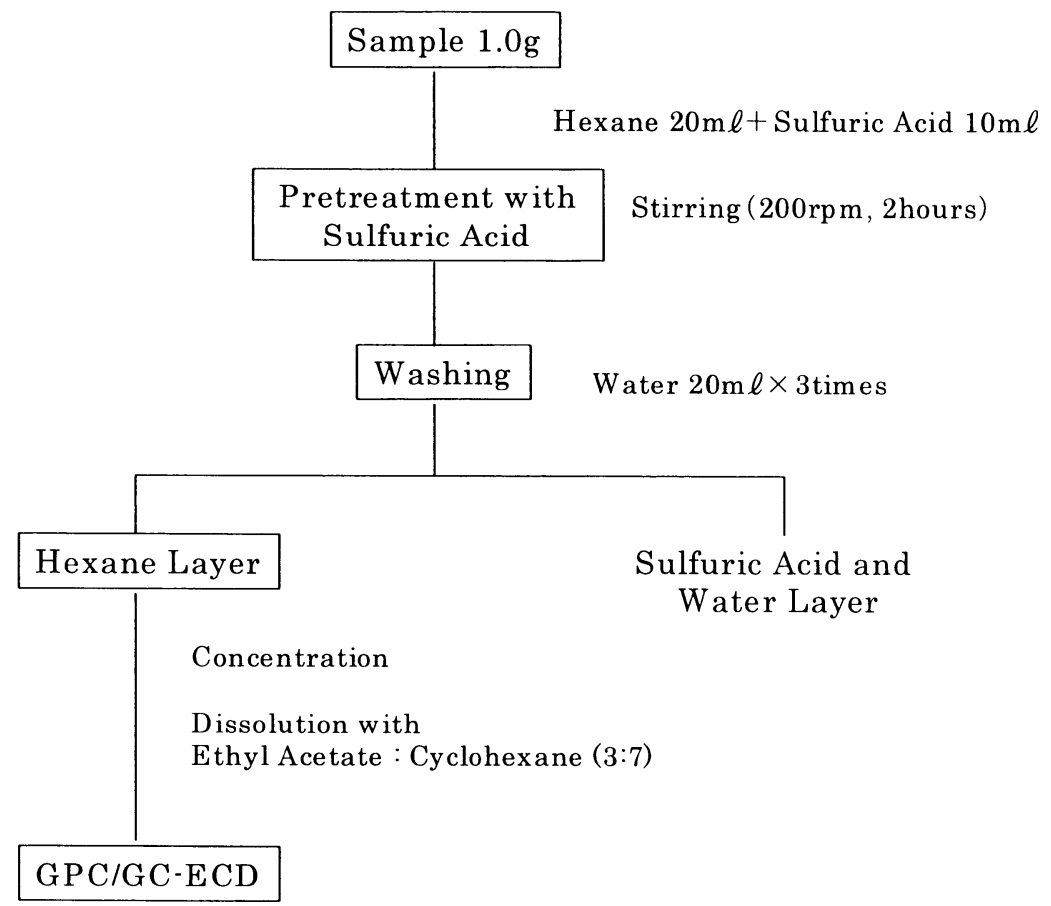

Fig. 7 Flow chart for pretreatment of insulating oil with sulfuric acid 


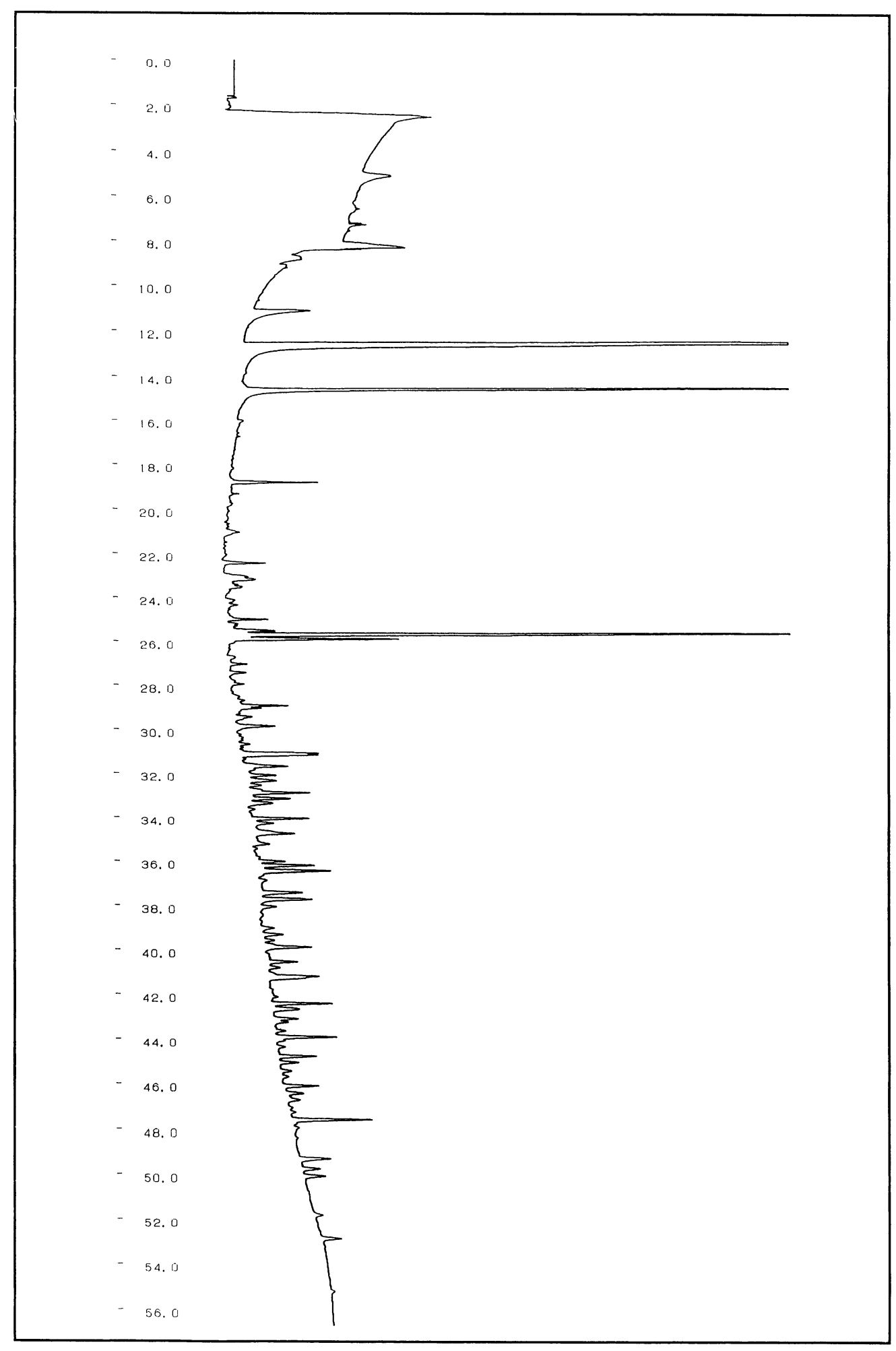

Fig. 8 Chromatogram of waste oil with $0.5 \mathrm{ppm}$ PCBs added 


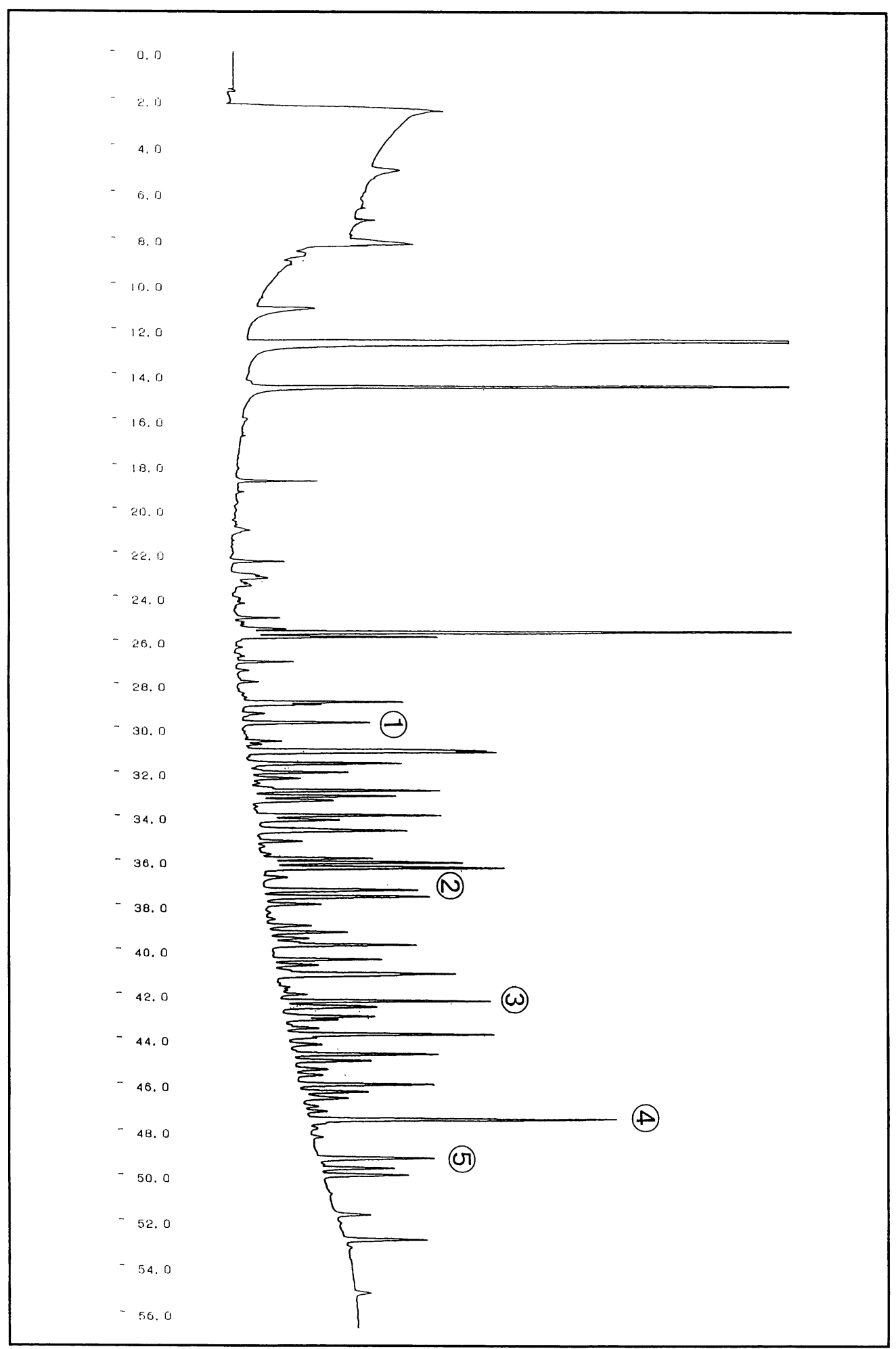

Fig. 9 Chromatogram of waste oil with $2.0 \mathrm{ppm}$ PCBs added 
分析自動化について検討を行った。

(1) 既存の HPLC と GC を組み合わせ, 絶縁油と PCB を GPC 法にて分離した後, PCB のみをオンラインで GC の PTV に導入し, GC-ECD で分析する GPC/GC システムを構築した。

(2) PCB 標準品を用いて自動化のための分析条件の最 適化を行った後, 硫酸処理を施した PCB 標準品添 加 $(0.5 \mathrm{ppm})$ 絶縁油（廃油）試料を用いて分析を
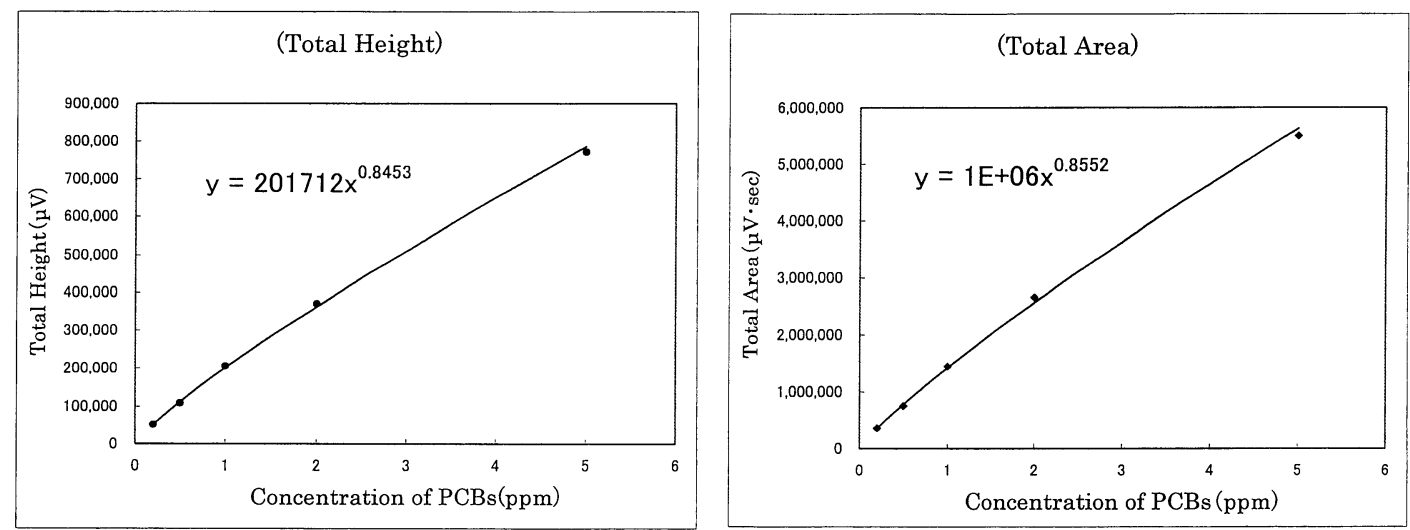

Fig. 10 Calibration curves for PCBs

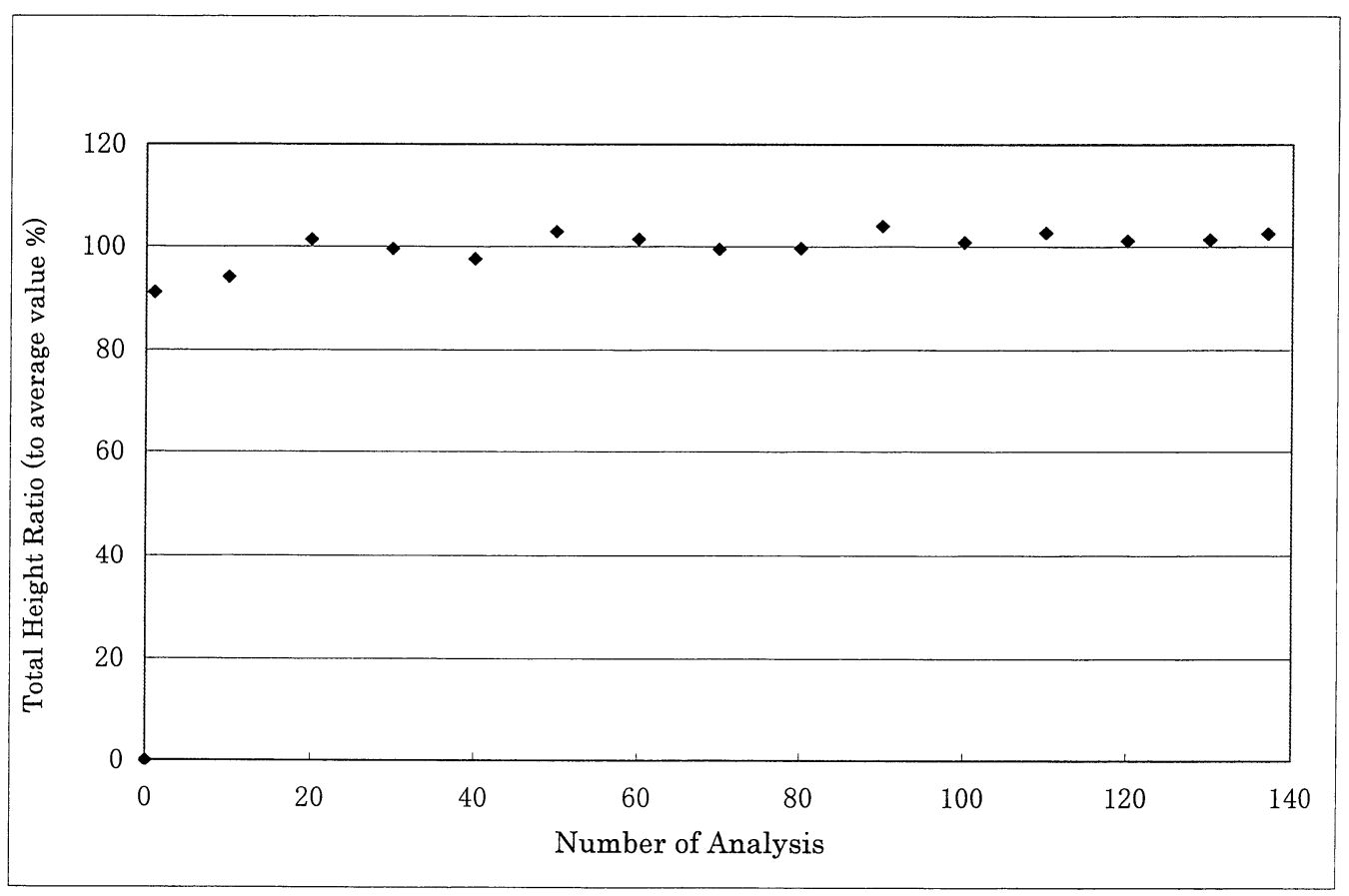

Fig. 11 Change of total peak height 
暫くは徐々に増加する傾向があるが，その後安定す ること, 各ピークの分離状態はほとんど変わらない ことを確認した。

（５）しかし，僅かに残留する絶縁油中成分の影響で PCB の保持時間が徐々にではあるが長時間方向へシフト していくことが判った。検査対象試料数が数百に及 ぶような場合は, 精度の高い自動分析を行うために 絶縁油除去効率をさらに上げる等の方策が必要であ る。

\section{要 約}

現在, 低濃度 PCB 污染絶緣油確認のために簡便で精 度の高い分析手法が求められている。しかし, 一般的 に, 絶縁油中の微量な PCB を分析するには絶縁油除去 のための前処理操作，分析操作に多くの時間と熟練した 技術を要する。本研究では分析に要する労力を軽減する ことを目的とし, オンライン GPC/GC を用いて絶縁油中 の低濃度 PCB 自動分析法の確立を図った。GPC/GC は既 存の HPLC と GC を用いて構築した。PCB 標準品を用い て自動化のための分析条件の最適化を行った後, 絶縁油 (廃油)にPCB 標準品を添加した試料を硫酸処理し, 本 法で分析した結果, 繰り返し再現性3.3〜6.8\%, 検出下 限做0.10ppm, 定量下限値0.34ppm を得た。また, 約 1 週間の連続分析を行い、安定した自動分析が可能である ことを確認した。本システムは低濃度 PCB 污染絶縁油 の高精度連続スクリーニング分析に適用可能であると考
える。

\section{文 献}

1）田中伸行：PCB の簡易測定法の検討-妨害成分の分 離手法の簡便化, 大気環境学会年会講演要旨集, 42 (2001)

2) 待井泰人ら：ガスクロマトグラフィー/負化学イオ ン化質量分析による絶縁油中 PCB の迅速分析, 環 境化学, 13，959-971（2003）

3）松原英隆，仙波芳崇：絶縁油中の PCBs 分析におけ るゲルクロマトグラフィーを用いた前処理方法, 環 境化学, 13, 1033-1040（2003）

4) Kobayashi, N., Arimoto, H. and Nishikawa, Y.: Simultaneous determination of polymer average molar mass and molar mass distribution, and concentration of additives by GPC-GC. J. Microcolumn Separations, 12, 501-507 (2000)

5）佐々木晃一, 佐々木哲也ら：廃油中のポリ塩素化ビ フェニル $(\mathrm{PCBs})$ 前処理法の検討, 第 9 回環境化 学討論会要旨集, 240-241（2000）

6) 大井悦男, 河添雅弘ら：PCB 迅速分析のための HPLC 自動前処理方法の検討および GC/MS 測定, 第15回廃棄物学会研究発表会講演論文集, 13401342 (2004)

7）澤津橋徹哉，塚原千幸人ら： $\mathrm{PCB}$ 迅速モニタリング 技術と装置化に関する研究，環境化学，15，61-81 (2005) 